\title{
Article
}

\section{Nondestructive Analysis of Wall Paintings at Ostia Antica}

\author{
Bernhard Blümich ${ }^{1, *}{ }^{\mathbb{C}}$, Eleonora Del Federico ${ }^{2}$, Denis Jaschtschuk ${ }^{1}$, Markus Küppers ${ }^{1}{ }^{\mathbb{D}}$, Katelin Fallon ${ }^{2}$, \\ Adelaide Steinfeld ${ }^{2}$ and Paolo Tomassini ${ }^{3}$ (1) \\ 1 Institut für Technische und Makromolekulare Chemie, RWTH Aachen University, Worringerweg 1, \\ 52074 Aachen, Germany; Jaschtschuk@itmc.rwth-aachen.de (D.J.); Kueppers@itmc.rwth-aachen.de (M.K.) \\ 2 Department of Mathematics and Science, Pratt Institute, Brooklyn, NY 11205, USA; \\ edelfede@pratt.edu (E.D.F.); kfallon@pratt.edu (K.F.); asteinfe@pratt.edu (A.S.) \\ 3 History, Art and Archaeology Faculty, University of Louvain, 1348 Louvain-la-Neuve, Belgium; \\ paolo.tomassini@uclouvain.be \\ * Correspondence: bluemich@itmc.rwth-aachen.de
}

check for updates

Citation: Blümich, B.; Del Federico, E.; Jaschtschuk, D.; Küppers, M.; Fallon, K.; Steinfeld, A.; Tomassini, P. Nondestructive Analysis of Wall Paintings at Ostia Antica. Heritage 2021, 4, 4421-4438. https://doi.org/ $10.3390 /$ heritage4040244

Academic Editor: Valeria Di Tullio

Received: 29 September 2021

Accepted: 15 November 2021

Published: 20 November 2021

Publisher's Note: MDPI stays neutral with regard to jurisdictional claims in published maps and institutional affiliations.

Copyright: (C) 2021 by the authors Licensee MDPI, Basel, Switzerland. This article is an open access article distributed under the terms and conditions of the Creative Commons Attribution (CC BY) license (https:/ / creativecommons.org/licenses/by/ $4.0 /)$.

\begin{abstract}
Roman wall paintings at Ostia Antica were studied for the first time in situ in an integrated approach using nuclear magnetic resonance (NMR) depth profiling, portable X-ray fluorescence (XRF), and visible induced luminescence (VIL) in order to explore the materials used in their construction and gain insight into the evolution of the Roman painting technique over time. NMR revealed the signatures of covered wall paintings through details of the structure of the top painted mortar layers, and the loss of this information that can be encountered when paintings are detached from the wall for preservation purposes. XRF provided information about the pigment composition of the paintings, and VIL was used to identify Egyptian Blue. Egyptian Blue was only found in the earlier wall paintings studied dating from 1st century B.C.E. to the 1st century C.E. The pigment palette seems to become limited to iron-based pigments in the later paintings, whereas the palette of the earlier paintings appears to be more varied including mercury, lead, and copper-based pigments.
\end{abstract}

Keywords: Ostia Antica; wall painting; mobile NMR; portable XRF; VIL

\section{Highlights}

- NMR depth profiles reveal the mortar-layer signature of hidden wall paintings

- NMR suggests a doubling of the top mortar layer in high-quality wall paintings

- The mortar-layer stratigraphy is destroyed when detaching wall paintings from the wall for preservation

- VIL suggests that Egyptian blue was used mostly in earlier and higher quality wall paintings

\section{Introduction}

Ostia was the ancient harbor city of Rome during Antiquity. Located at the mouth (Latin: Ostium) of the river Tiber, it was born as a military settlement to protect the nearby city of Rome, the capital of the Roman Empire, and control trade across the sea. The city has a history almost as long as Rome itself: Founded, according to the sources, by king Ancus Marcius in the 7th century B.C.E., it was inhabited until at least the 6th century C.E. Today, Ostia Antica is one of the biggest and richest archaeological sites in Italy, with more than 34 ha excavated, mostly between 1939 and 1942. Large areas of the city have been brought to light, revealing a large number of public and private buildings. Many of these buildings still have their wall, floor, and (in some cases) ceiling decorations, offering a complete and accurate view of the taste and trends in Roman times.

Nondestructive analytical methods are essential tools in cultural heritage diagnostics [1]. Depth profiling with mobile NMR instruments is a comparatively new method in the portfolio of cultural heritage and art diagnostics [2-10]. The measurement explores the hydrogen concentration and mobility of molecules similar to magnetic resonance imaging (MRI) [11,12]. Variations in the hydrogen concentration and environment define the 
contrast in NMR depth profiles of layered materials. Moisture content, in porous media in particular, is straightforward to quantify and has been investigated to study the prevailing moisture in a wall painting [3], and other materials such as wood [13] as well as the performance of stone consolidants [2,14].

Several wall paintings and wall painting fragments dating from the 1st century B.C.E. to the 3rd century C.E. were investigated in Ostia Antica [15] by NMR depth profiling [16], portable X-ray fluorescence (XRF) [17], and visible induced luminescence (VIL) [18-21] to explore the materials used in their construction. This work expands a long-term collaboration of the Pratt Institute in Brooklyn with RWTH Aachen University [22-24], and with the Université Catholique de Louvain to analyze wall paintings in an art historical context [15]. Combining pigment analysis and depth profiling of painted walls has unveiled hitherto hidden similarities among wall painting fragments as well as painted walls supported by computer-assisted comparison of a large set of NMR depth profiles based on principle-component analysis [24,25]. This relationship could now be tracked in remnants of Egyptian blue in earlier and higher-quality wall paintings in Ostia Antica. The signature of hidden wall paintings could be identified in NMR depth profiles for the first time, and the stratigraphy of the top mortar layer in high-quality wall paintings was found to be consistent with an application of that layer in two steps. It is found that during detachment and conservation of wall paintings, the information provided by NMR depth profiling of the mortar-layer stratigraphy is lost.

\section{Materials and Methods}

\subsection{Materials}

A selection of fragments was measured in the archeological storage facility of the site along with a detached wall painting and a number of wall paintings from five different buildings, which are shown in Figure 1.

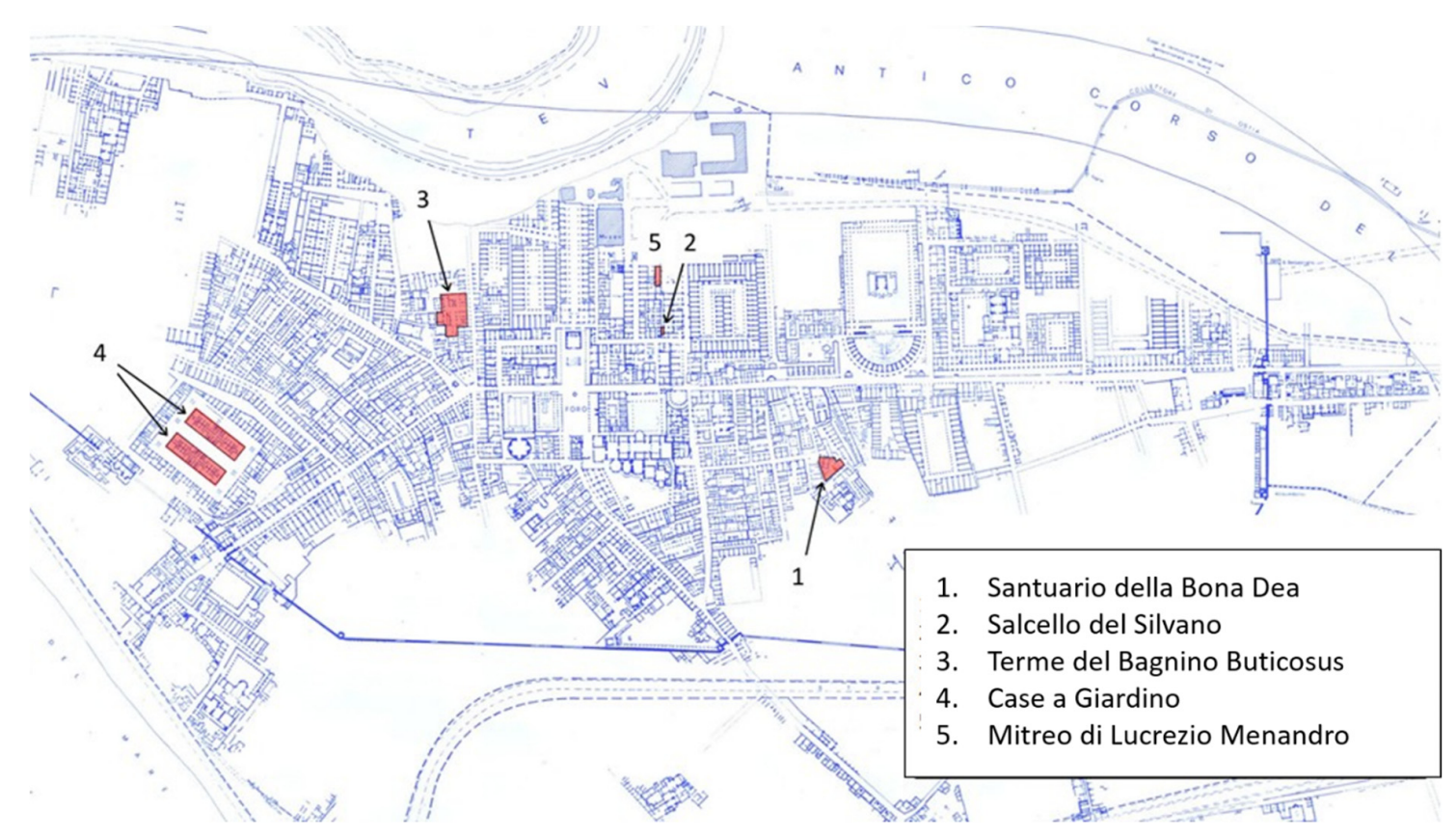

Figure 1. Map of Ostia Antica showing the investigated sites in red.

The Santuario della Bona Dea (Sanctuary of the Good Goddess), located in the Fifth Region of the city, is one of the few buildings of the city that still preserves Third and Fourth Styles paintings in situ, dated between the end of the 1st century B.C.E. and the beginning of the 1st century C.E. The most recent paintings have been detached, conserved, and reattached to a steel grid with a ventilation gap between the grid and the wall. The Third-Style paintings, located in the cellar of the temple, are still attached to the wall 
and only partially excavated, dating to the earlier construction of the temple (1st century B.C.E.).

The Terme del Bagnino Buticosus (Baths of the Attendant Buticosus) was built at the turn of the 1st century C.E. and refurbished at the beginning of the 3rd century C.E. [26] At this time, the painted west wall of room 1 with niches was decorated with a second, painted mortar layer of low quality.

The Case a Giardino (Garden Houses) are a compact complex of living spaces and shops constructed during the 2nd century C.E. between 123 and 125 A.D [27].

The Mitreo di Lucrezio Menandro (Mithraeum of Lucretius Menander). The mithraeum was built at the very end of the 2 nd century C.E. inside a former apartment house. This house was decorated with rich wall paintings during the second half of the 1st century C.E., and the paintings were kept in place when the building was transformed into a mithraeum [28].

The Chapel of Silvano (Salcello del Silvano) built in the 3rd century C.E. was a cult room dedicated to the deity, "Silvano", which is located in the Mill houses (Caseggiato dei Molini) [28]. Due to time constraints, this room was only investigated by XRF and VIL.

\subsection{NMR Depth Profiles}

The NMR depth profiles are numbered as 'spot $n$ ' in this work (Table 1). The walls measured are described as follows:

The Santuario della Bona Dea: Two areas were measured on the detached paintings (spots 1,2). The third site measured (spot 3 ) was chosen on a wall painting from the cellar and still attached to the wall for comparison.

The Terme del Bagnino Buticosus: Two areas were measured a niche apart (spots 4,5).

The Case a Giardino: Two areas were investigated, one on an outside wall protected by a modern roof (spot 6) and one on an inside wall perpendicular to the outside wall (spot 7).

Table 1. Location and description of the spots studied by NMR.

\begin{tabular}{|c|c|c|c|}
\hline Location & Description & Spot Number & Photo \\
\hline Santuario della Bona Dea & $\begin{array}{l}\text { detached wall } \\
\text { painting }\end{array}$ & 1,2 & \\
\hline Santuario della Bona Dea & wall section & 3 & \\
\hline $\begin{array}{c}\text { Terme del Bagnino } \\
\text { Buticosus }\end{array}$ & wall sections & 4,5 & \\
\hline Case a Giardino & $\begin{array}{l}\text { wall sections front } \\
\text { and side }\end{array}$ & 6,7 & \\
\hline
\end{tabular}


Table 1. Cont.

\begin{tabular}{cccc}
\hline Location & Description & Spot Number & Photo \\
\hline $\begin{array}{c}\text { Mitreo di Lucrezio } \\
\text { Menandro }\end{array}$ & wall sections & 8,9 & \\
Nuovi Depositi & & & \\
fragments & $10,11,12$ &
\end{tabular}

In the Mitreo di Lucrezio Menandro, two areas (spots 8 and 9) were studied, each in a different room. Spot 8 is located in room 2, which belongs to the earlier time period of the building construction. Spot 9 is located in the newer room and to the left of the Mithraeum altar.

The wall painting fragments were selected according to their art-historical importance and with attention to the available information on the absence of water-repellent conservation treatments. The latter is important as in order to properly collect NMR depth profiles, the porous material needs to be able to take up water, which becomes the source of the NMR signal. The wall painting fragment with spot 10 derives from the second half of the 1st century C.E. The fragment with spot 11 showed two painted mortar-layer assemblies: An older one from the 1st century B.C.E. was covered with a newer one from the end of the 1st century C.E. The fragment with spot 12 has an intense red color. It dates from the 1st century B.C.E. and is the oldest fragment studied in this project. It represents a beautiful Second-Style monochrome landscape. Contrary to the painted walls, all fragments were moisturized from both sides for NMR depth profiling to approach maximum moisture saturation across their entire thickness.

The NMR measurements were conducted with a Magritek PM25 Profile NMR-MOUSE with a maximum depth of access of $25 \mathrm{~mm}$ at a $1 \mathrm{H}$ NMR frequency of $13.85 \mathrm{MHz}$ (Figure 2a). The measured signal is the decay of the transverse nuclear magnetization (Figure 2b) established in the stray field of a strong permanent magnet, which is the dominant component of the NMR-MOUSE. The signal is acquired with a multi-echo sequence following Carr, Purcell, Meiboom, and Gill, employing an echo time of $\mathrm{tE}=120 \mu \mathrm{s}$ and a pulse width of $25 \mu \mathrm{s}[11,12]$. A total number of 64 echoes was recorded composing one CPMG decay, and 256 scans were averaged with a recycle delay of $0.25 \mathrm{~s}$ at one sensor position. Depending on the water saturation and the material properties, the acquired NMR signal decays in a non-exponential fashion. Its amplitude reports the number of hydrogen atoms in the sensitive slice. It scales with the moisture content. The signal decay is analyzed in this work in terms of a sum of decaying exponential functions with characteristic NMR relaxation times $T_{2}$ and inverted into a distribution of relaxation times (Figure 2c). Although formally imprecise, this inversion is known as an inverse Laplace transformation [11,12]. The recorded signal derives from a roughly square-shaped sensitive slice with a $40 \mathrm{~mm}$ 
edge, which, depending on the measurement parameters, is about $0.2 \mathrm{~mm}$ thick. This slice is located at a fixed distance of $25 \mathrm{~mm}$ above the sensor surface. To acquire a depth profile, the sensitive slice was shifted across the range of interest inside the wall by changing the distance between the sensor and the wall in steps of $0.25 \mathrm{~mm}$. Before acquiring a depth profile, the spot under investigation was moisturized several times with a mist of demineralized water from a spray bottle. For the water to be absorbed by the painted wall, it is important that the surface has not been treated with wax or another water-repellent substance. Even then, it took more than $30 \mathrm{~min}$ for the water to permeate to depths of $18 \mathrm{~mm}$ and more. Because of that, the shift direction of the NMR-MOUSE between scans was set towards the wall in the forward direction of the water migration into the object in order to accelerate the measurement process. In this way, three to four depth profiles could be acquired in a day's work.
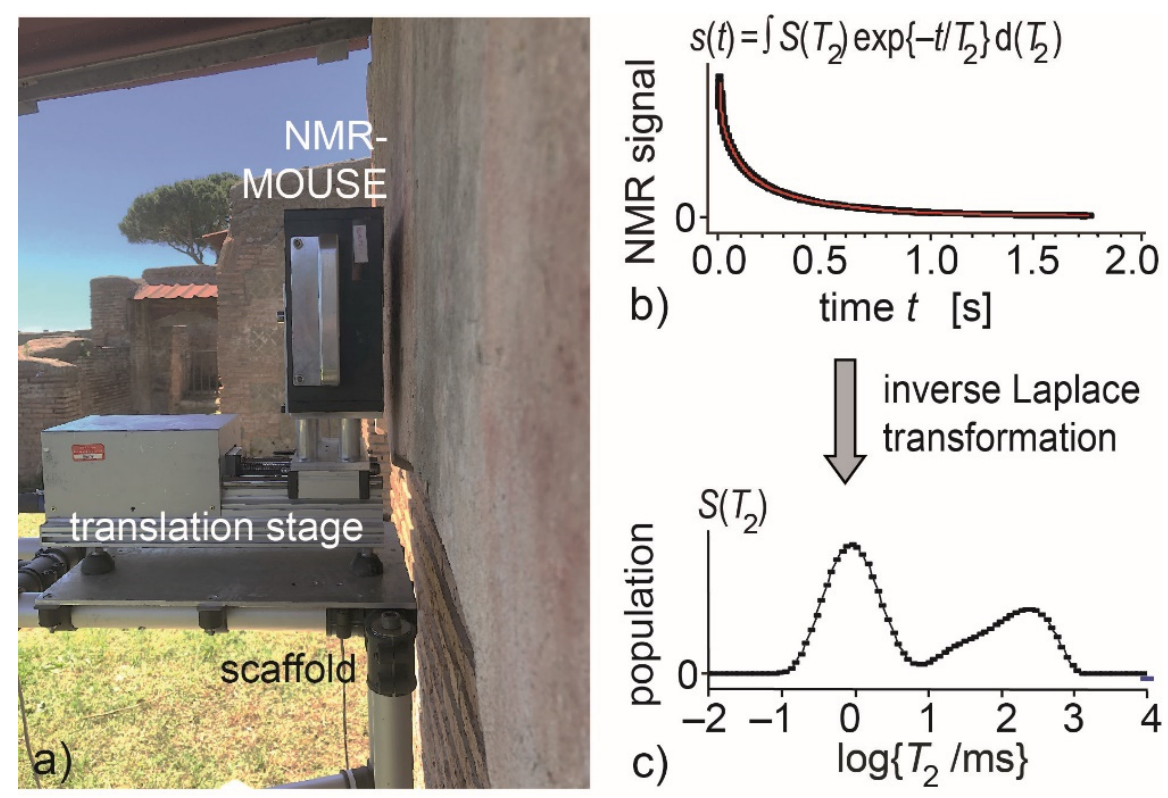

Figure 2. Measuring with the NMR-MOUSE. (a) The NMR-MOUSE set up on a translation stage, which rests on a scaffold, ready to measure a depth profile at the Case a Giardino. (b) The measured signal is a function that decays with time. (c) Inverse Laplace transformation decomposes the signal decay into a distribution of relaxation times $T_{2}$.

\subsection{Portable X-ray Fluorescence (XRF)}

The elemental composition of the painting surfaces, i.e., the possible pigments present were investigated in situ with a portable X-Ray Fluorescence (XRF) spectrometer: Bruker AXS Tracer III/IV® [17] operating at a voltage of $40 \mathrm{kV}$ and a current of $1.15 \mu \mathrm{A}$ with nonfiltered Rhodium radiation with which elements of atomic number $13(\mathrm{Al})$ and higher can be detected. All measurements were acquired with an accumulation time of $30 \mathrm{~s}$.

\subsection{Visible Induced Luminescence (VIL)}

The presence of Egyptian Blue was determined with Visible Induced Luminescence (VIL) [18-21]. A Fuji FinePix S digital camera was modified by removing the inbuilt UV/IRblocking filter and replacing it with a NIR high pass filter. Two Nissin Di700A flashes with UV/IR cut filters served to excite the IR luminescence of the Egyptian Blue pigment. All measurements were acquired in the dark with tarps surrounding the camera to block stray radiation. 


\section{Results}

\subsection{Hidden Wall Paintings}

From the wall painting fragments investigated at the Nuovi Depositi (the archeological storage facility), the one with spot 11 showed two painted mortar-layer assemblies. The covered, older one dates from the 1st century B.C.E. and the newer one from the end of the 1st century C.E. (Figure 3a). It was customary to cover older wall paintings with newer ones as the walls accumulated the traces of time and the style of decoration changed over the years. The newer layer of the fragment was a bit thinner than the access range of the NMR-MOUSE, so that the onset of the covered, older wall painting was within reach of the depth profile. The moisture-content profile shows a rich structure, typical of several mortar layers [23]. The depth-resolved distribution of relaxation times exhibits a peak at long relaxation time near $10 \mathrm{~ms}$ across the entire range up to $16 \mathrm{~mm}$ with varying amplitude, suggesting that free water has permeated throughout all layers of the fragment. Both the moisture-content profile and the depth-resolved distribution of relaxation times are discontinuous at the same depth of $17 \mathrm{~mm}$ as that measured with a ruler on the fragment (Figure 3a). Little to no water is taken up in the interface region between the newer and the older covered wall paintings. The very first millimeters of both wall paintings are characterized by a peak at long relaxation times near $10 \mathrm{~ms}$ and one at shorter relaxation times near $0.2 \mathrm{~ms}$, suggesting similar surface properties of both wall paintings. These signatures in the NMR depth profiles set a reference for other depth profiles, where a covered wall painting is not confirmed by other means.
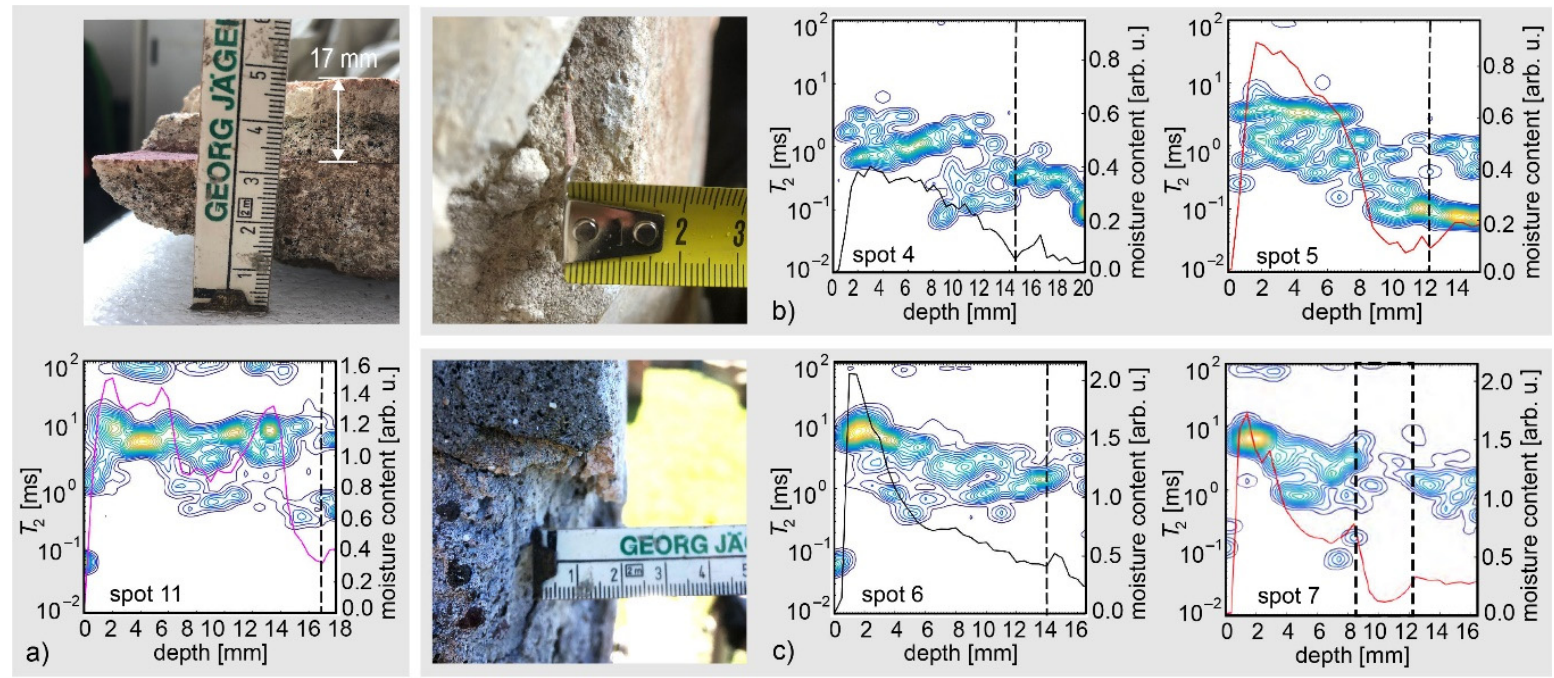

Figure 3. Depth profiles of covered wall paintings. (a) A fragment from the Nuovi Depositi showing two layers of wall paintings. (b) The west wall of room 1 of the Terme del Bagnino Buticosus exhibits a new mortar layer covering an older one. (c) The Case a Giardino appeared to have a doubling of the mortar layer stratigraphy on the outside wall (left) while the mortar layers were partially detached at the inside wall (right).

Contrary to fragments, wall paintings on walls can only be moisturized from one side, so that the signal intensity decreases with depth. This was the case for the two profiles measured in the Terme del Bagnino Buticosus (Figure 3b; spots 4, 5) and the two profiles from the Case a Giardino (Figure 3c; spots 6, 7). Two profiles were acquired at the niched west wall of room 1 of the Terme del Bagnino Buticosus, one niche apart (Figure 3b, middle, right; spots 4,5$)$. Heavy rain challenged the measurement, but the sensitive equipment could be protected in one of the roofed niches, assisted by an umbrella and a tent. The original wall paintings had been refurbished with an uneven, newer, painted mortar layer of low quality. The covered, older painted layer revealed its existence at a damaged edge on the left side of the wall (Figure 3b, left). Although the water-saturation levels are different, both depth profiles show similar moisture-content profiles with a second peak beginning 
to build up at $15 \mathrm{~mm}$ and $12 \mathrm{~mm}$ depths. This discontinuity in the moisture-content depth profiles is also evidenced in the depth-resolved relaxation-time distributions by a disruption of the peak at long relaxation times and a noticeable change in amplitude of the peak at short relaxation times. The peak at short relaxation times is only detected in certain depth ranges, suggesting a layered mortar base, which is only recognized in the moisture content profiles upon close inspection. With decreasing moisture content, the signal in the distributions at long relaxation time shifts towards shorter relaxation time and decreases in intensity. This results from the fact that the signal at long relaxation times derives from water that is freer to move through large pores by wetting and drying, while the signal at shorter relaxation times comes from water confined to small pores and pore walls, which cannot move easily $[11,29]$. In view of that and the fact that spot 5 (Figure $3 b$, right) has taken up more than double the moisture of spot 4 (Figure 3b, middle), the depth-resolved relaxation-time distributions are also reminiscent of the reference depth profile (Figure 3a) for spot 11 of the covered wall painting fragment.

The Case a Giardino is an integrated complex of living spaces and shops built between 123 and 125 C.E. Based on quality and accessibility, a painted wall outside and one inside were chosen for measurement. The wall painting on the outside wall was still well attached to the original brick wall. A crumbled edge revealed that the mortar layers applied in the preparation of the painting appeared to have been doubled (Figure $3 c$, left). While the moisture-content profile of spot 6 (Figure 3c, middle) reports a simpler mortar stratigraphy of this wall than for the fragment in the depository (Figure 3a; spot 11), it resembles the profiles measured at the Terme del Bagnino Buticosus (Figure 3b; spots 4, 5). A second peak starts to appear at a $14 \mathrm{~mm}$ depth consistent with the onset of a second layer structure. In the depth-resolved relaxation-time distribution, the peak at the long relaxation time has faded away, and another peak begins to rise with increasing depth. The envelope of the peak positions in the depth direction slightly declines with increasing depth at long relaxation times and increases at short relaxation times. This observation agrees with the interpretation that there is less water in the larger pores at a larger depth and even less water in the smaller pores, consistent with the moisture-content profile decreasing with depth.

To investigate if this doubling of the mortar stratigraphy was limited to the outer wall, another spot was measured at an inner wall perpendicular to the outer one (Figure 3a, right; spot 7). The depth profile resembles that of spot 6 in the first $8 \mathrm{~mm}$, but then the signal amplitude drops significantly for the next $4 \mathrm{~mm}$ before it rises again (Figure 3c, right). In view of the somewhat lower moisture content in spot 7 , the relaxation-time distributions of both spots appear similar, except for the gap between 8 and $12 \mathrm{~mm}$. This provides evidence that the mortar layers at spot 7 had separated at $8 \mathrm{~mm}$, a point where the relaxation-time distribution at spot 6 (Figure 3c, middle) changes noticeably, indicating a transition to another layer. The existence of a gap was also confirmed acoustically when slightly knocking on the painted wall. Unfortunately, the gap is too wide to access the depth, where the onset of a second stratigraphy could be expected, such as that in spot 6 .

The onset of peaks in moisture-content depth profiles at characteristic depths, here 14 to $17 \mathrm{~mm}$, is the most obvious evidence in NMR depth profiles indicating a hidden wall painting. Depth-resolved relaxation-time distributions are more difficult to read because peak amplitudes and peak positions not only depend on the material properties of the mortar layers but also on the water saturation, which decreases with depth and is hard to control experimentally. However, along with the moisture-content profiles, depth-resolved relaxation-time distributions suggest that a new set of layers leaves its signature in a discontinuity of the peak at long relaxation times.

\subsection{Stratigraphy of the Top Mortar Layers in Wall Paintings of High Quality}

Some of the depth profiles from high-quality wall paintings revealed a striking similarity in the first few millimeters, showing two prominent peaks. This is well visible in the first $6 \mathrm{~mm}$ of the wall painting fragment in Figure 3a (spot 11) while in the profiles from 
the Case a Giardino (Figure 3c; spots 6 and 7), such a splitting may also be indicated in the first $3 \mathrm{~mm}$ by a hump on the right of the prominent surface peak towards a higher depth. The splitting is also visible in the first 5 to $6 \mathrm{~mm}$ of the two profiles measured at the Mitreo di Lucrezio Menandro (Figure 4a; spots 8,9), whereby spot 9 took up only about one-third of the water compared to spot 8 , and the very first $3 \mathrm{~mm}$ take up even less water. The fragment with spot 10 (Figure $4 \mathrm{~b}$, left) shows a peak slitting, such as that of spot 8 on the wall of the Mitreo (Figure 4a, left), but the fragment with spot 12 (Figure 4b, right) shows only one peak and only takes up a very small amount of water. The intricate structure of the NMR depth profiles relates to the way the wall had been prepared for painting with a sequence of mortar layers with decreasing grain size towards the surface as described by Vitruvius [30]. The very first layer can be applied in two steps, the first one at the time of building up the layer structure and the second one at the time right before painting. Among others, this technique is documented in a house at Pompeii, where the work of wall painting was discontinued by the eruption of Mount Vesuvius in the year 79 C.E. [31,32]. This doubling of the first layer is hypothesized to be seen by the two peaks in the range from 0 to $6 \mathrm{~mm}$ of the depth profiles from high-quality wall paintings.

The water at spot 12 (Figure $4 \mathrm{~b}$, right) resides in the small pores as seen in the high peak intensity of the depth-resolved distribution of relaxation times at a short relaxation time. Interestingly, the amount of absorbed water increases with increasing depth. This feature and the pronounced difference in water uptake between the different fragments and wall sections is well visualized when the moisture-content profiles are drawn on the same scale (Figure 4c). The fact that there are such large differences in water absorption capacity suggests that the observed amount of water taken up results not only from different mortar formulations and variations in the wetting procedure but that the fragments and walls with low water uptake had been treated with a water-repellent substance, information that had been unavailable at the time of measurement.
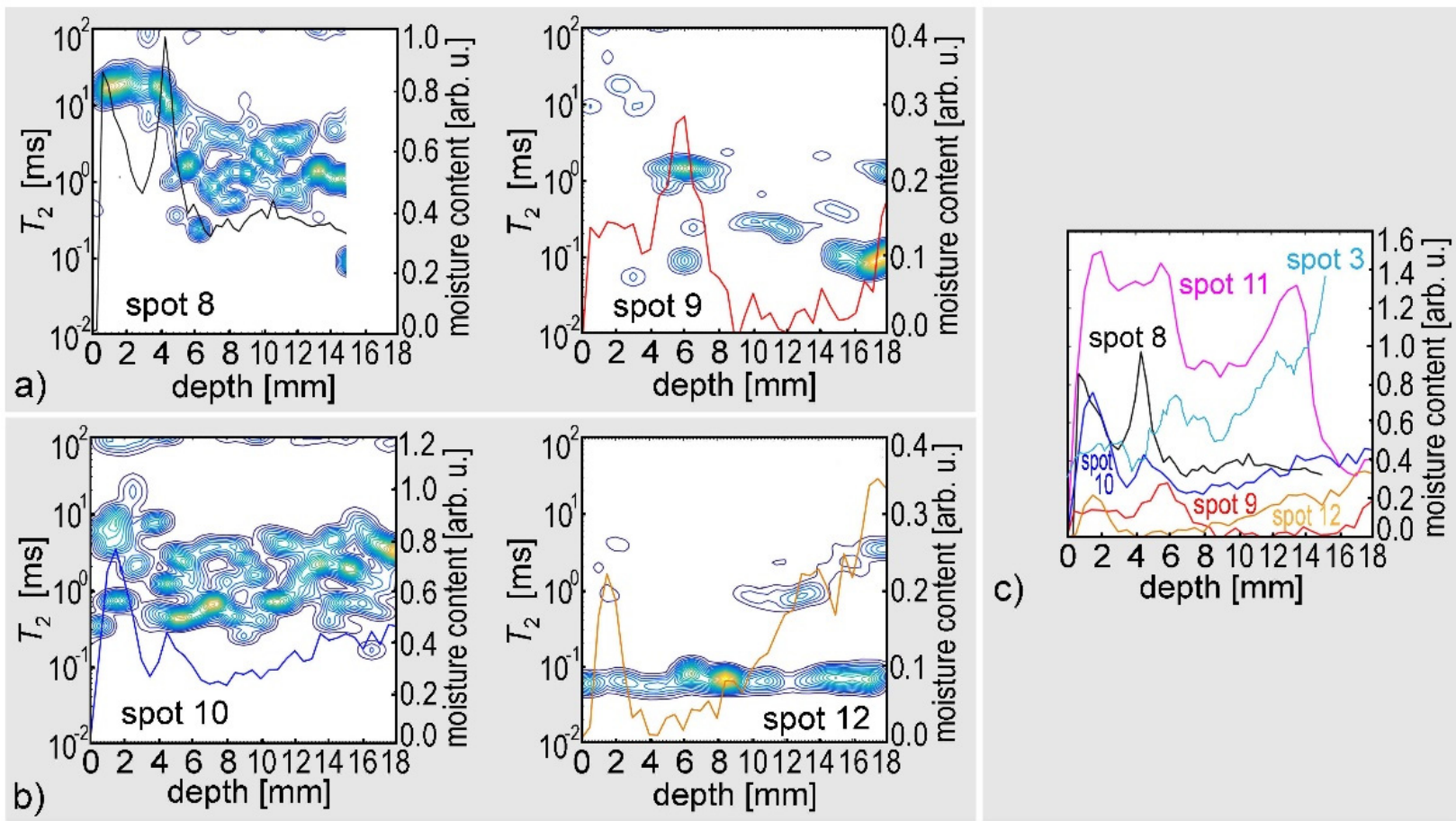

Figure 4. Depth profiles from wall paintings of high quality. (a) Mitreo di Lucrezio Menandro (spots 8, 9). (b) Fragments from the Nuovi Depositi (spots 10,12). (c) Comparison of moisture-content depth profiles including that of the fragment with spot 3 . 


\subsection{NMR Depth Profiles of Wall Paintings in Different Conditions of Preservation and Conservation}

Not all wall paintings are suited for NMR depth profiling, and this is because the NMR signal comes from a proton-rich substance in the pore space of the mortar-layer structure. Demineralized water is the natural fluid of choice because it is readily available and does not harm the painting when applied slowly as a fine mist as indicated by the archeologists on site. Wall paintings that have been treated with a water-repelling agent such as wax and certain stone strengtheners will not take up water easily. One example is the fragment with spot 12 (Figure $4 b$, right), which appears to have been treated predominantly from the front where the water ingress is lower than from the back. On the other hand, the photo showing the side view of the fragment suggests a far richer layer structure (Figure 5c). A similar situation, albeit not as pronounced, is encountered with spot 10 (Figure $5 b$ ). The photo suggests a layer structure such as that of the fragment with spot 11 (Figure 5a), but the fragment takes up less water, and the water content profile reveals only two peaks without further detail. Whereas the layer structure of a wall painting treated with wax, or some other water-repellent substance, is not irreversibly lost, it is, however, in the case of restoration processes involving the detachment of the painting from the wall. This is the situation encountered with a wall painting in the Santuario della Bona Dea. A wide wall painting section of Fourth Style, located in the portico around the temple, had been detached from the wall, secured on an iron grid, and placed back onto the wall with a gap in between for air ventilation (Figure 5d). Depth profiles (spots 1 and 2) were challenging to measure, because it was cumbersome to ensure water was absorbed into the painted structure, suggesting a water-repellent surface treatment. In addition to that, the steel frame on which the detached wall painting was mounted attracted the magnet of the NMR-MOUSE. However, the attraction force was weak enough to be controlled so that two depth profiles could be measured, albeit at an apparent, and not the true, depth scale. The apparent position of the sensitive slice is shifted due to the distortion of the stray magnetic field of the sensor by the iron grid (Figure $5 \mathrm{~d}$; spots 1 and 2). Both moisture-content profiles are uninformative, because the original mortar layers had been ground down to a thin surface layer during the restoration process to apply a new backing to the painted surface. On the other hand, the profile from spot 3 of a partially excavated wall painting still on its original wall and belonging to an early-phase construction of the building (1st century B.C.E.) reports a different mortar stratigraphy (Figure 5e; spot 3). Despite spraying the surface with water, the moisture content is low at the surface but increases steeply with increasing depth. The low surface moisture is not surprising in view of the measurement having been conducted on a hot day with the surface exposed to the sun and the structure taking up the surface spray water very quickly. The high moisture content further inside the wall is likely to be capillary water from the ground. Unfortunately, the signal-to-noise ratio is low, so the depth-resolved distribution of relaxation times appears fragmented. Nevertheless, two water populations can be identified, one near $T_{2}=10 \mathrm{~ms}$ belonging to water in large pores and one near $T_{2}=0.1 \mathrm{~ms}$ from water confined to small pores. 

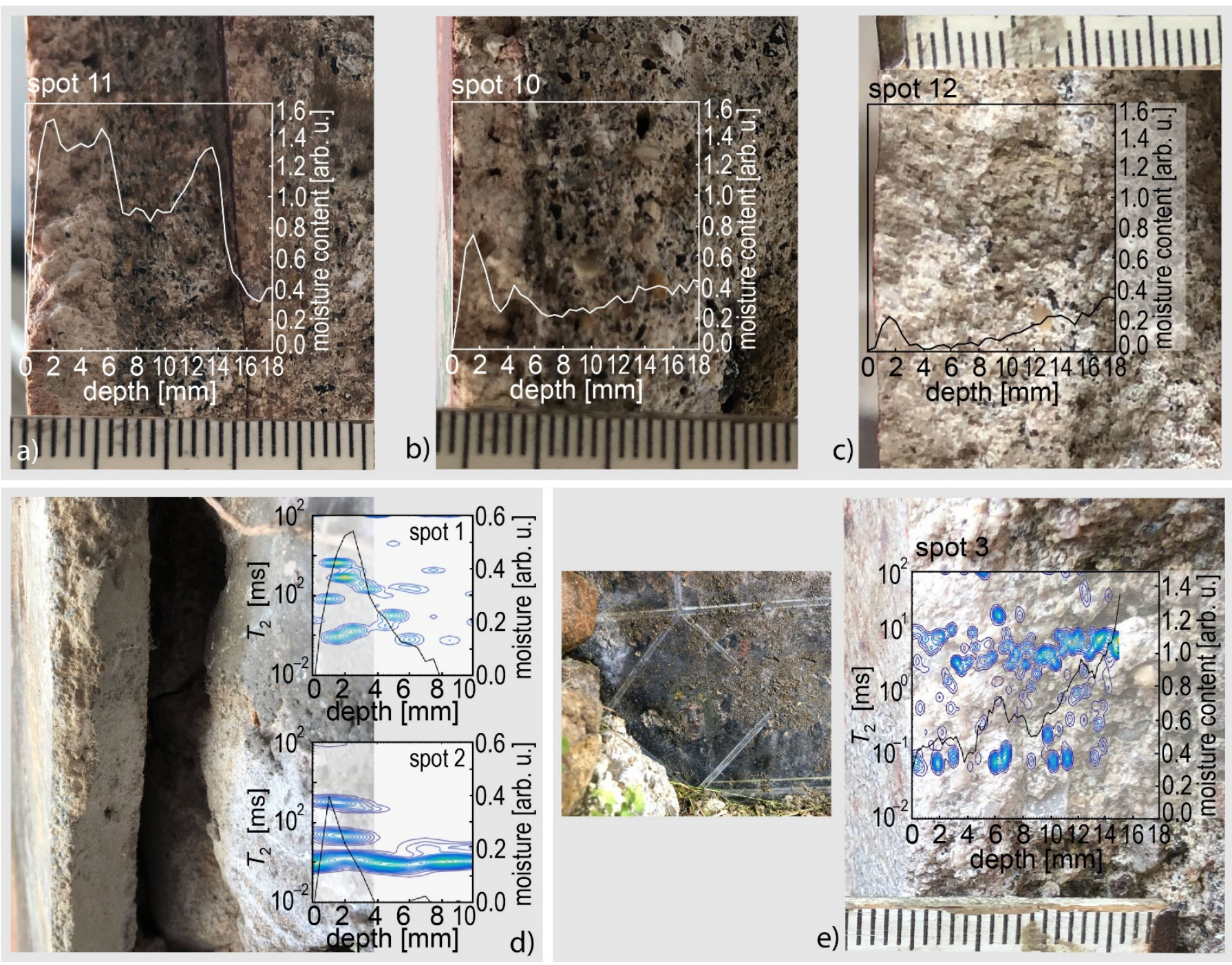

Figure 5. Signatures of wall painting conservation treatment in NMR depth profiles of moisture content overlaid on photos of their stratigraphy. (a) The untreated wall painting fragment with spot 11. (b) The wall painting fragment with spot 10. (c) The fragment with spot 12. (d) Depth profiles from spots 1 and 2 of the detached wall painting in the Santuario della Bona Dea. (e) Profile from spot 3 of a wall painting still on its original wall close to the ground in close vicinity to the detached wall painting. On the left of the measured spot, the picture of a face appeared after wetting the wall.

\subsection{XRF and VIL Results}

The elemental compositions of the areas studied by NMR were also analyzed by portable XRF and VIL to gain information about the pigments use and to correlate the wall stratigraphy with its surface composition. Although XRF only gives information on the elemental make up of the areas studied, the determination of the possible pigments present can be aided by the knowledge of their availability with time (circa 1st century B.C.E.-3rd century C.E.). In recent years, there has been an increased interest in the study of ancient Roman pigments and new information is now available [33-47]. Most of these studies, however, have been performed in the laboratory on either wall painting fragments or samples. Moreover, there have only been a few studies of the pigment composition of fragments of Ostian wall paintings [48-51]. The work presented here represents the first in situ integrated approach in the analysis of Ostian wall paintings that still remain on-site in their original buildings. 
All areas analyzed by XRF display a high signal intensity for calcium. This is expected due to the use of lime mortars in the wall preparation. Strontium is also always present and also to be expected, as it is a common impurity found in limestone, the raw material for the preparation of lime mortars. In addition, sulfur is also always found as a trace element, whereby outdoor walls display a much higher Sulfur signal intensity. It is possible that the Sulfur signal from the outdoor walls results from sulfate efflorescences, although this cannot be confirmed with XRF and would need to be further investigated by XRD, FTIR or Raman. The XRF spectra of the areas corresponding to spots 3 and 8 studied by NMR were the only ones that showed the presence of copper. These areas were also analyzed by VIL to confirm the presence of Egyptian Blue. Table 2 shows the elemental compositions at the areas of spots 1-9 and 12 studied by NMR. Due to time constraints at the archeological site, and the time constraints of the number of experiments that could be performed per day, it was not possible to analyze spots 10 and 11 by XRF nor VIL. Likewise, "spot 13", the site at the Salcello del Silvano, was only investigated by XRF and VIL but not by NMR due to the same time limitations.

Figure 6 shows the XRF spectra for the NMR-measured spots 1, 2, and 3 of the Santuario della Bona Dea (Figure 6a-c, respectively) and at the Terme del Bagnino Buticosus (Figure $6 \mathrm{~d}, \mathrm{e}$ ). Spot 1 , which is located on a red area of the wall painting, mainly exhibits a high-intensity signal for iron and so the red pigment is assigned to an iron-based red (e.g., Red Ochre), although the use of organic lakes cannot be discarded and would need to be further investigated by molecular techniques such as FTIR or Raman spectroscopy. Spot 2, located on a black area of the painting, mainly shows the presence of iron and manganese, so the pigment is attributed to iron and manganese-based compounds such as umber. However, the presence of an additional black pigment such as carbon black cannot be ruled out by XRF. Spot 3 displays a richer palette, with the presence of yellows, red, green, blue, and black pigments. Their elemental compositions (Table 2 and Figure 6c) suggest the presence of Iron-based yellow, red, and green along with a copper-based blue, later identified as Egyptian Blue by VIL. The black background is indirectly attributed to carbon black, because of the lack of manganese and phosphorous, which would indicate possible umber and bone black, respectively, on spot 3 . Figure $6 \mathrm{~d}$,e shows the XRF spectra obtained at the Terme del Bagnino Buticosus. Both spots 4 (Figure 6d) and 5 (Figure 6e) mainly display a high signal for iron and therefore the red pigment is attributed to an iron-based red. 

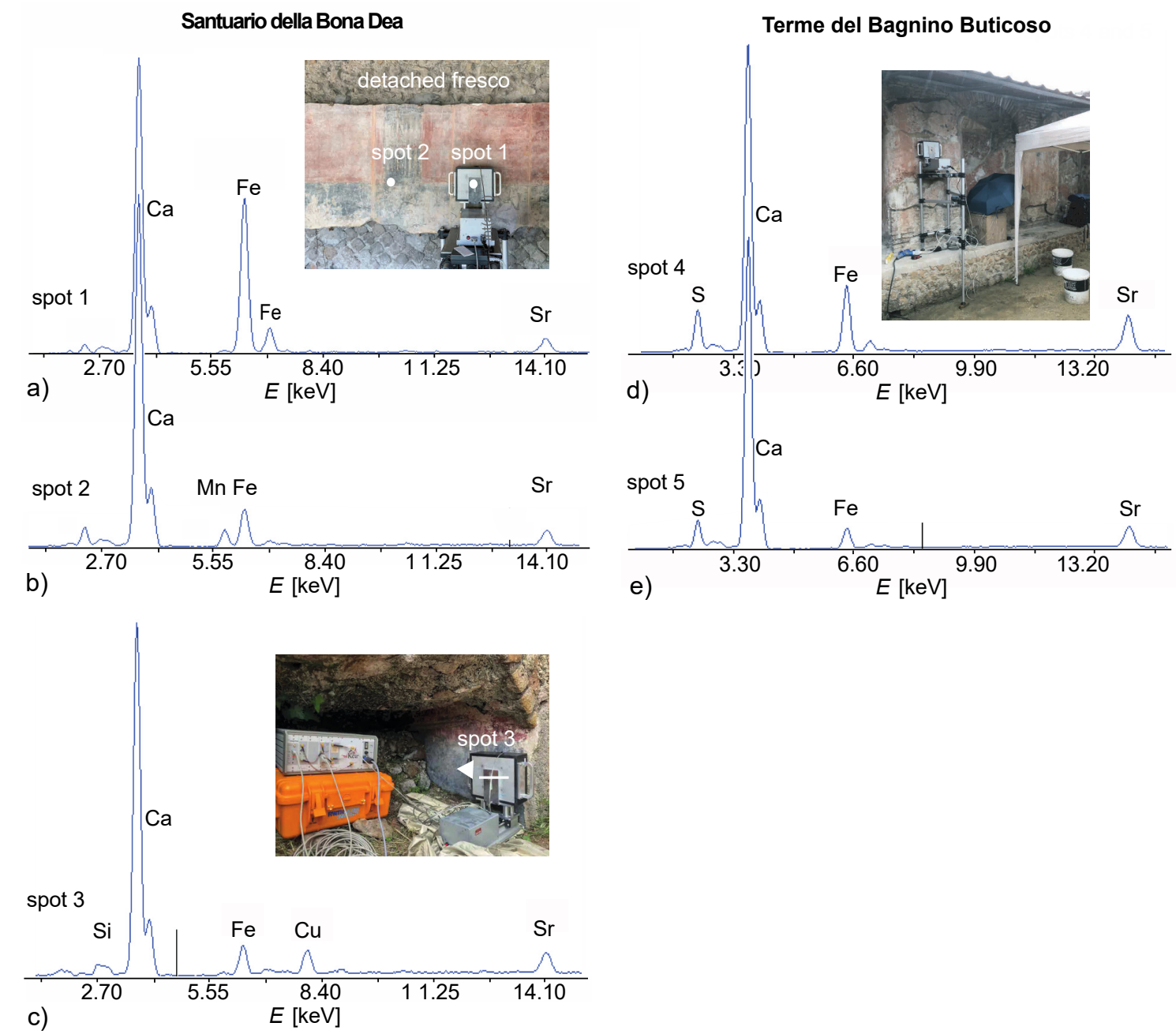

Figure 6. XRF spectra of spots 1-5. (a-c) Spectra of spots1 to 3 acquired at the Santuario Della Bona Dea. (d,e) Spectra of spots 4 and 5 measured at the Terme del Bagnino Buticosus.

The XRF spectra of spots 6 and 7 acquired at Case a Giardino (Figure 7a,b) are very similar in their elemental composition, although spot 6 was measured on a yellow area and spot 7 on a red area. Both spectra also mainly display a high signal intensity for Iron and therefore the pigments on spots 6 and 7 were assigned to Iron-based yellow and red (e.g., red and yellow ochres). Figure 7 shows the spectra acquired at the Mitreo di Lucrezio Menandro on the NMR spots 8 (Figure 7c) and 9 (Figure 7d). The elemental composition of the area of spot 8 shows the presence of copper, which was later assigned to Egyptian Blue by VIL. This wall belongs to an early construction phase of the house dating to the later part of the 1st century C.E., before the Mitreo was built. Spot 8 is in an area that also displays white, green, and red pigments. Therefore, both red and green were assigned to iron-based pigments and white to lime white (calcium-containing white). 

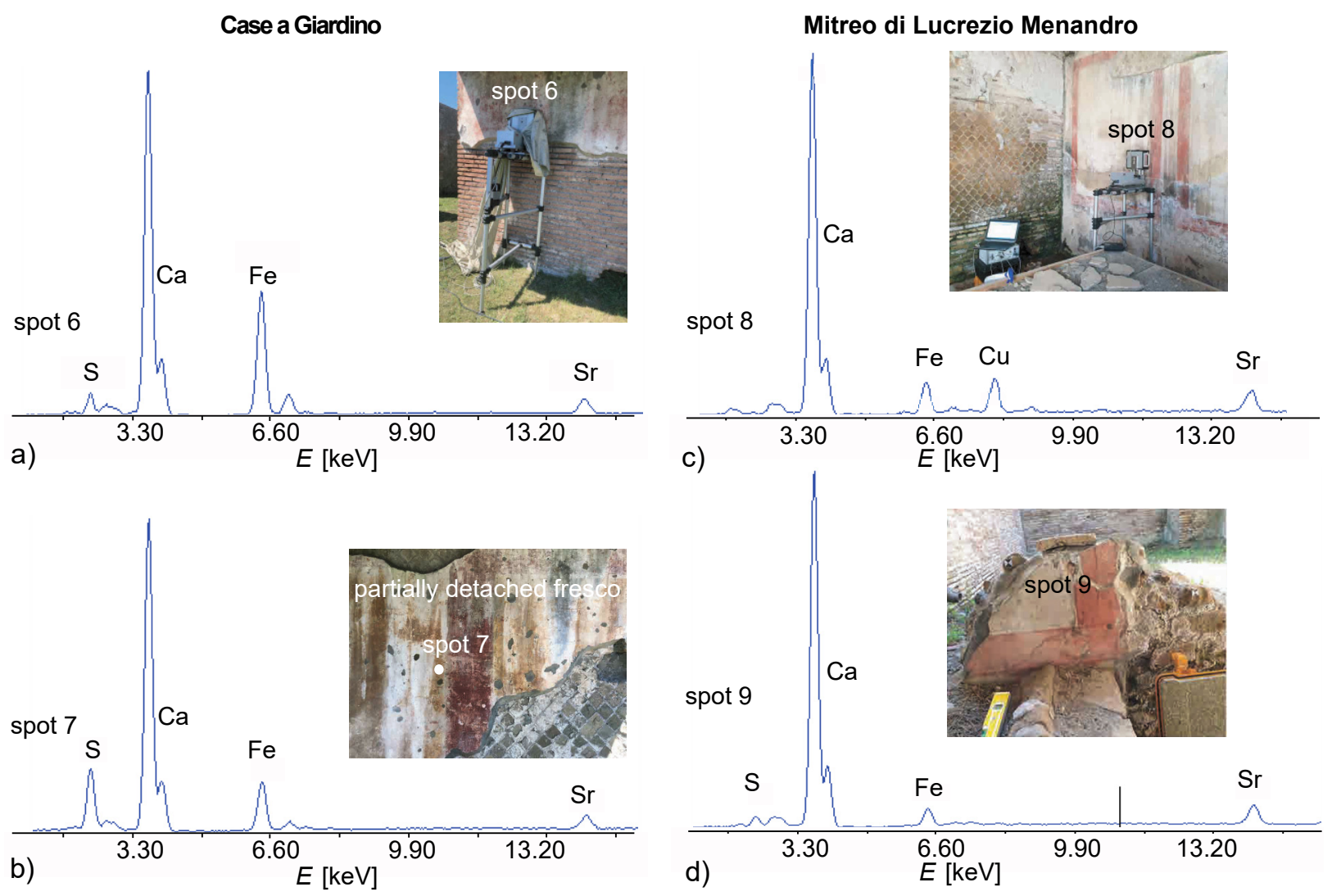

Figure 7. XRF spectra for spots 6 to 9. (a,b) Case del Giardino. (c,d) Mitreo di Lucrezio.

Figure 8 shows the XRF spectrum of spot 12, which displays a very high signal intensity for mercury, and therefore the red pigment is attributed to cinnabar (Hg), which appears to be of high purity given the low signal observed for iron, which would otherwise possibly indicate a mixture or layering of both cinnabar and an iron-based red.

Figure 9 shows the spectrum of the area corresponding to spot 13 at the Salcello del Silvano, a chapel or cult room that dates to the 3 rd century C.E. The spectrum shows a high signal for iron and calcium and the significant presence of lead. These signals are attributed to Iron and Lead-based pigments. Investigations of other areas of the wall painting do not show the presence of Lead (data not shown) and mainly display high signals for iron and calcium. It appears to be worthwhile to investigate whether the choice of pigment more expensive than the iron-based ones [52] on the clothes of Silvano may be due to its divinity status. Figure 10 shows the VIL images for the areas where Egyptian Blue was detected: at the Santuario della Bona Dea, spot 3 (Figure 10a) and the Mitreo di Lucrezio Menandro spot 8 (Figure 10b).

No Egyptian Blue was detected in any of the paintings studied that dated after the 1st century C.E. In addition, it is interesting to point out that the presence of cinnabar in spot 12 correlates with a mortar stratigraphy more complex than for spots 3 and 8 . A correlation between the presence of the expensive cinnabar, and a more complex and higher-quality mortar stratigraphy was also found in wall paintings at the Villa dei Papiri, in Herculaneum, dating to before the earthquake of 62 C.E. [23]. This correlation between more expensive pigments and its more complex layer preparation will be further investigated in future campaigns at both sites. 


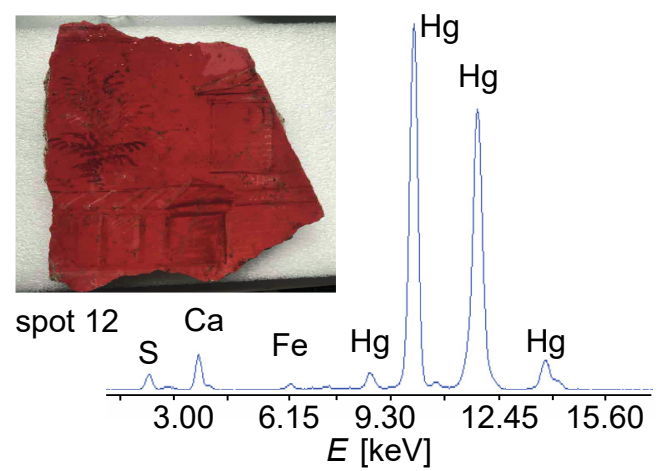

Figure 8. XRF spectra for spot 12 displaying the presence of mercury attributed to cinnabar.

\section{Sacelle del Silvano}

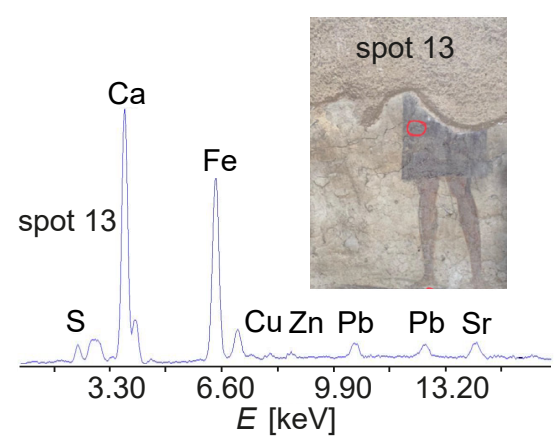

Figure 9. XRF spectra for spot 13 showing the presence of iron and traces of lead, which may indicate a mixture of iron and lead-based pigments.

a)
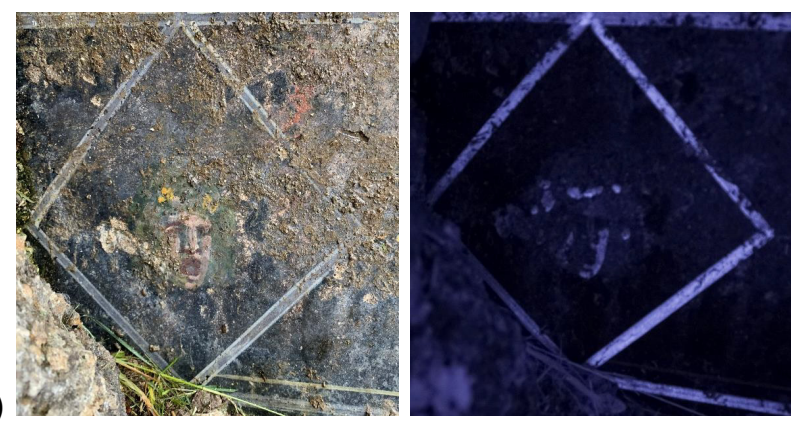

b)
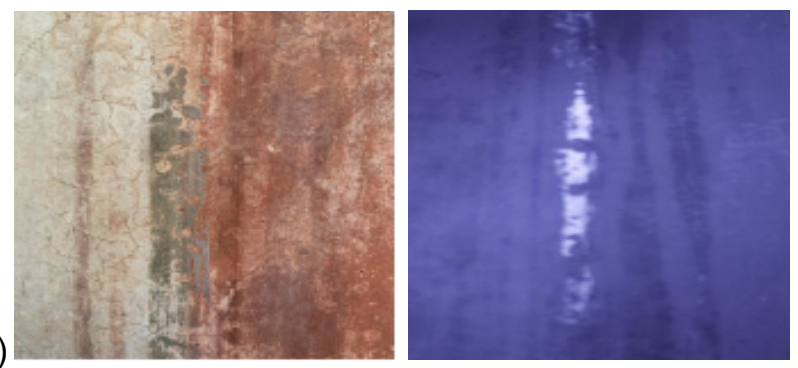

Figure 10. VIL of wall paintings and fragments containing Egyptian Blue and measured by NMR. (a) Spot 3 at the Santuario della Bona Dea. (b) Spot 8 at the Mitreo de Lucrezio Menandro. 
Table 2. XRF results for the different sites and fragments investigated.

\begin{tabular}{|c|c|c|c|c|c|}
\hline Building/Fragment & Spot & Date & Area studied & Elements Present & Pigments by XRF/VIL \\
\hline \multirow{3}{*}{$\begin{array}{c}\text { Santuario della Bona } \\
\text { Dea }\end{array}$} & 1 & $\begin{array}{l}\text { 1st } \\
\text { c C.E. }\end{array}$ & & $\mathrm{Ca}, \mathrm{Fe}, \mathrm{Sr}(\mathrm{S})$ & Iron-based red \\
\hline & 2 & $\begin{array}{l}1 \text { st } \\
\text { c C.E. }\end{array}$ & & $\mathrm{Ca}, \mathrm{Fe}, \mathrm{Mn}, \mathrm{Sr}(\mathrm{S})$ & Iron-Manganese based black \\
\hline & 3 & $\begin{array}{c}\text { 1st } \\
\text { c B.C.E. }\end{array}$ & & $\mathrm{Si}, \mathrm{Ca}, \mathrm{Fe}, \mathrm{Cu},(\mathrm{Pb})$ & $\begin{array}{l}\text { Iron-based yellow, red and } \\
\text { green, pigments, Egyptian Blue } \\
\text { (C black) }\end{array}$ \\
\hline \multirow{2}{*}{$\begin{array}{c}\text { Terme del Bagnino } \\
\text { Botiscus }\end{array}$} & 4 & $\begin{array}{l}\text { 3rd } \\
\text { c C.E. }\end{array}$ & & $\mathrm{Ca}, \mathrm{Fe},(\mathrm{Pb})$ & Iron-based red \\
\hline & 5 & $\begin{array}{l}\text { 3rd } \\
\text { c C.E. }\end{array}$ & & $\mathrm{Ca}, \mathrm{Fe}$ & Iron-based red \\
\hline \multirow[b]{2}{*}{ Case a giardino } & 6 & $\begin{array}{l}\text { 2nd } \\
\text { c C.E. }\end{array}$ & & $\mathrm{S}, \mathrm{Ca}, \mathrm{Fe}, \mathrm{Sr}$ & Iron -based yellow \\
\hline & 7 & $\begin{array}{l}\text { 2nd } \\
\text { c C.E. }\end{array}$ & & $\mathrm{S}, \mathrm{Ca}, \mathrm{Fe}, \mathrm{Sr}$ & Iron-based red \\
\hline \multirow{2}{*}{$\begin{array}{c}\text { Mitreo di Lucrezio } \\
\text { Menandro }\end{array}$} & 8 & $\begin{array}{l}\text { 1st } \\
\text { c C.E. }\end{array}$ & & (Si), $\mathrm{Ca}, \mathrm{Fe}, \mathrm{Cu}, \mathrm{Sr}$ & $\begin{array}{l}\text { Iron-based red, green and } \\
\text { yellows, Egyptian Blue, } \\
\text { Calcium-based white }\end{array}$ \\
\hline & 9 & $\begin{array}{l}\text { 2nd } \\
\text { c C.E. }\end{array}$ & & $\mathrm{Ca}, \mathrm{Fe}, \mathrm{Sr}$ & Calcium-based white \\
\hline Fragments & 12 & $\begin{array}{c}1 \text { st } \\
\text { c B.C.E. }\end{array}$ & & $\mathrm{S}, \mathrm{Ca}, \mathrm{Fe}, \mathrm{Hg}, \mathrm{Sr}$ & Cinnabar (HgS) \\
\hline Salcello del Silvano & 13 & $\begin{array}{l}\text { 3rd } \\
\text { c C.E. }\end{array}$ & & $\begin{array}{c}\mathrm{S}, \mathrm{Ca}, \mathrm{Fe}, \mathrm{Pb},(\mathrm{Cu}), \\
(\mathrm{Zn}), \mathrm{Sr}\end{array}$ & Iron and Lead-based pigments \\
\hline
\end{tabular}

\section{Conclusions}

The present study is the first integrated in situ approach to the investigation of the materials and techniques of the wall paintings at Ostia Antica that remain on site at their original settings. The NMR results presented here have shown that it is possible to suggest the presence of an earlier hidden painting below a newer one without the need for destructive sampling. This was shown repeatedly both on fragments as well as on the wall paintings studied at the site. NMR has also shown that the mortar stratigraphy information is lost when wall paintings are detached from their original sites for preservation purposes, whereby the painting surface is preserved but the information on the construction and wall preparation is lost through the removal process.

XRF and VIL analyses of the paintings suggest that a richer pigment palette seems to be present in earlier wall paintings and the artists' palette seems to become limited to earth colors (iron-based pigments) with the rare use of lead pigments and the apparent "loss" of Egyptian blue on the later paintings (2nd-3rd centuries C.E.). This is also observed in a recent study on Ostian wall painting fragments dating from the 2nd Century B.C.E. 
to the 1st century C.E. [51]. A pigment palette containing red and yellow ochres, green earth, cinnabar, Egyptian blue along with lead white is found in paintings dating to that period. However, the study does not provide information on wall paintings dating to after the 1st century C.E. It is interesting to point out that the present XRF study did not detect chromium on the green areas analyzed in contrast to the presence of chromium in several of the fragments investigated in [51].

The earlier wall paintings studied here also display a more complex NMR stratigraphy, which could be correlated to the presence of a richer pigment palette including Egyptian Blue and precious pigments such as cinnabar, although this needs to be investigated further. Additional studies both on buildings of different time periods and fragments are in need to tighten the correlation of NMR stratigraphy and pigment use.

Although the presence of organic coatings can be inferred by poor water uptake of the wall paintings, we plan to include in situ FTIR analyses, which will allow us to confirm the presence of coatings and reveal their composition. Moreover, the pigments will be further investigated with the use of a portable Raman spectrometer along with FTIR, which will allow us to further interpret the XRF results presented here.

Author Contributions: Conceptualization: K.F., E.D.F. and B.B.; Data curation: D.J., M.K. and A.S.; Formal analysis: D.J. and E.D.F.; Investigation: D.J., M.K., K.F. and A.S.; Project administration: B.B., M.K., P.T. and E.D.F.; Supervision: B.B., P.T. and E.D.F.; Original draft: D.J.; Review and editing: B.B., P.T., M.K., K.F., A.S. and E.D.F. All authors have read and agreed to the published version of the manuscript.

Funding: B.B., D.J. and M.K. acknowledge IPERION-CH, Grant Agreement No. 654028 in the H2020 Program of the EU, for partial financial support. EDF thanks Pratt Institute's School of Liberal Arts and Sciences Faculty Research Fund and AS thanks the Itzak Friedman Endowed Scholarship.

Institutional Review Board Statement: Not applicable.

Informed Consent Statement: Not applicable.

Acknowledgments: The authors warmly thank the Parco Archeologico di Ostia Antica, and especially its former Director Maria Rosaria Barbera, its current Director Alessandro D'Alessio, Claudia Tempesta, Tiziana Sorgoni, and Antonella Docci, for having supported and facilitated our research. We thank Yesenia Valle Mora and Stephanie Wong, Pratt students for their assistance in the setting up and acquisition of VIL and XRF data. EDF thanks Margaret Dy-So and Carole Sirovich for their kind support.

Conflicts of Interest: The authors declare no conflict of interest.

\section{References}

1. Pinna, D.; Galeotti, M.; Mazzeo, R. (Eds.) Scientific Examination of Paintings. Handbook for Conservator-Restorers; Centro Di: Florence, Italy, 2010.

2. Sharma, S.; Casanova, F.; Wache, W.; Segre, A.; Blümich, B. Analysis of historical porous building materials by the NMR-MOUSE ${ }^{\circledR}$. Magn. Reson. Imag. 2003, 21, 249-255. [CrossRef]

3. Proietti, N.; Capitani, D.; Rossi, E.; Cozzolino, S.; Segre, A.L. Unilateral NMR study of a XVI century wall painted. J. Magn. Reson. 2007, 186, 311-318. [CrossRef] [PubMed]

4. Blümich, B.; Casanova, F.; Perlo, J.; Presciutti, F.; Anselmi, C.; Doherty, B. Noninvasive testing of art and cultural heritage by mobile NMR. Acc. Chem. Res. 2010, 43, 761-770. [CrossRef]

5. Capitani, D.; Di Tullio, V.; Proietti, N. Nuclear magnetic resonance to characterize and monitor cultural heritage. Prog. Nucl. Magn. Reson. Spectr. 2012, 64, 29-69. [CrossRef]

6. Baias, M. Mobile NMR: An essential tool for protecting our cultural heritage. Magn. Reson. Chem. 2017, 55, 33-37. [CrossRef] [PubMed]

7. Baias, M.; Blümich, B. Nondestructive testing of objects from cultural heritage with NMR. In Modern Magnetic Resonance; Webb, G., Ed.; Springer: Cham, Switzerland, 2018; pp. 293-304.

8. Rehorn, C.; Blümich, B. Cultural heritage studies with mobile NMR. Angew. Chem. Int. Ed. 2018, 57, 7304-7312. [CrossRef] [PubMed]

9. Blümich, B.; Perlo, J.; Casanova, F. Mobile single-sided NMR. Prog. Nucl. Magn. Reson. Spectr. 2008, 52, 197-269. [CrossRef]

10. Casanova, F.; Perlo, J. Single-Sided NMR, 1st ed.; Blümich, B., Ed.; Springer: Berlin/Heidelberg, Germany, 2011.

11. Blümich, B. Essential NMR, 2nd ed.; Springer Nature: Cham, Switzerland, 2019. 
12. Blümich, B.; Haber-Pohlmeier, S.; Zia, W. Compact NMR; de Gruyter: Berlin, Germany, 2014.

13. Casieri, C.; Senni, L.; Romagnoli, M.; de Luca, F.; Santamaria, U. Determination of moisture fraction in wood by mobile NMR device. J. Magn. Reson. 2004, 171, 364-372. [CrossRef]

14. Brizi, L.; Camaiti, M.; Bortolotti, V.; Fantazzini, P.; Blümich, B.; Haber-Pohlmeier, S. One and two-dimensional NMR to evaluate the performance of consolidants in porous media with a wide range of pore sizes: Applications to cultural heritage. Micro. Meso. Mat. 2018, 269, 186-190. [CrossRef]

15. Jaschtschuk, D. Advances in Low-Field NMR Relaxometry. Ph.D. Thesis, RWTH Aachen University, Aachen, Germany, 2019.

16. Perlo, J.; Casanova, F.; Blümich, B. Profiles with microscopic resolution by single-sided NMR. J. Magn. Reson. 2005, 176, 64-70. [CrossRef]

17. Shugar, A.; Mass, J. Handheld XRF in Art and Archeology; Leuven University Press: Leuven, Belgium, 2012.

18. Accorsi, G.; Verri, G.; Bolognesi, M.; Armaroli, N.; Clementi, C.; Miliani, C.; Romani, A. The exceptional near-infrared luminescence properties of cuprorivaite (Egyptian blue). Chem. Commun. 2009, 23, 3392-3394. [CrossRef] [PubMed]

19. Verri, G. The spatially resolved characterization of Egyptian blue, Han blue and Han purple by photo-induced luminescence digital imaging. Anal. Bioanal. Chem. 2009, 394, 1011-1021. [CrossRef] [PubMed]

20. Verri, G.; Saunders, D.; Ambers, J.; Sweek, T. Digital mapping of Egyptian blue: Conservation implications. Stud. Conserv. 2010, 55, 220-224. [CrossRef]

21. Verri, G.; Saunders, D. Xenon flash for reflectance and luminescence (multispectral) imaging in cultural heritage applications. Br. Mus. Tech. Bull. 2014, 8, 83-92.

22. Blümich, B.; Haber, A.; Casanova, F.; Del Federico, E.; Boardman, V.; Wahl, G.; Stilliano, A.; Isolani, L. Noninvasive depth profiling of walls by portable nuclear magnetic resonance. Anal. Bioanal. Chem. 2010, 397, 3117-3125. [CrossRef]

23. Haber, A.; Blümich, B.; Souvorova, D.; Del Federico, E. Ancient Roman wall paintings mapped nondestructively by portable NMR. Anal. Bioanal. Chem. 2011, 401, 1441-1452. [CrossRef] [PubMed]

24. Rehorn, C.; Kehlet, C.; Del Federico, E.; Zia, W.; Meldrum, T.; Blümich, B. Automatizing the comparison of NMR depth profiles. Strain 2018, 54, e12254. [CrossRef]

25. Rehorn, C.W.G. Studies of Tangible Cultural Heritage with Portable Stray-Field NMR. Ph.D. Thesis, RWTH Aachen University, Aachen, Germany, 2019.

26. Baccini Leotardi, P. Pitture con Decorazioni Vegetali dalle Terme, Monumenti della Pittura Antica Scoperti in Italia III, 5; Polygraphic Institute and State Mint-State Archives: Rome, Italy, 1978.

27. Falzone, S.; Zimmermann, N. Stratigrafia orizzontale delle pitture delle Case a Giardino. Modello della fase originaria dei blocchi centrali del complesso ostiense. AnzWien 2010, 145, 107-160. [CrossRef]

28. Oome, N. The caseggiato del mitreo di lucrezio menandro (I iii 5). A Case-study of wall painting in Ostia 1. BABesch 2007, 82, 232-246.

29. Blümich, B.; Anferova, S.; Kremer, K.; Sharma, S.; Herrmann, V.; Segre, A. Unilateral NMR for quality control: The NMR-MOUSE ${ }^{\circledR}$ Spectroscopy 2003, 18, 18.

30. Vitruvius, M.P. Ten Books on Architecture (De architectura libri decem); Cambridge University Press: Cambridge, UK, 1999.

31. Varone, A. L'organizzazione del lavoro di una bottega di decoratori: Le evidenze dal recente scavo pompeiano lungo via dell'Abbondanza. Meded. Van Het Ned. Inst. Rome 1995, 24, 124-136.

32. Varone, A.; Béarat, H. Pittori romani al lavoro. Materiali, strumenti, tecniche: Evidenze archeologiche e dati analitici di un recente scavo pompeiano lungo Via dell'Abbondanza (Reg. IX Ins.12). In Proceedings of the International Workshop on Roman Wall Paiinting, Fribourg, Switzerland, 7-9 March 1996; pp. 199-214.

33. Beeston, R.F.; Becker, H. Investigation of ancient Roman pigments by portable $\mathrm{x}$-ray fluorescence spectroscopy and polarized light microscopy. ACS Symp. Ser. 2013, 1147, 19-41.

34. Aliatis, I.; Bersani, D.; Campani, E.; Casoli, A.; Lottici, P.; Mantovana, S.; Marino, I. Pigments used in Roman wall paintings in the Vesuvian area. J. Raman Spectrosc. 2010, 41, 1537-1542. [CrossRef]

35. Amadori, M.L.; Barcelli, S.; Poldi, G.; Ferrucci, F.; Andreotti, A.; Baraldi, P.; Colombini, M.P. Invasive and non-invasive analyses for knowledge and conservation of Roman wall paintings of the Villa of the Papyri in Herculaneum. Microchem. J. 2015, 118, 183-192. [CrossRef]

36. Clementi, C.; Ciocan, V.; Vagnini, M.; Doherty, B.; Tabasso, M.L.; Conti, C.; Brunetti, B.G.; Miliani, C. Non-invasive and micro-destructive investigation of the Domus Aurea wall painting decorations. Anal. Bioanal. Chem. 2011, 401, 1815-1826. [CrossRef]

37. Crupi, V.; Galli, G.; La Russa, M.F.; Longo, F.; Maisano, G.; Majolino, D.; Malagodi, M.; Pezzino, A.; Ricca, M.; Rossi, B.; et al. Multi-technique investigation of Roman decorated plasters from Villa dei Quintili (Rome, Italy). Appl. Surf. Sci. 2015, 349, 924-930. [CrossRef]

38. Dal Fovo, A.; Mazzinghi, A.; Omarini, S.; Pampaloni, E.; Ruberto, C.; Striova, J.; Fontana, R. Non-invasive mapping methods for pigments analysis of Roman mural paintings. J. Cult. Herit. 2015, 43, 311-318. [CrossRef]

39. Duran, A.; Jimenez de Haro, M.C.; Perez-Rodriguez, J.L.; Franquelo, M.L.; Herrera, L.K.; Justo, A. Determination of pigments and binders in Pompeian wall paintings using synchrotron radiation-high-resolution x-ray powder diffraction and conventional spectroscopy—chromatography. Archaeometry 2010, 52, 286-307. [CrossRef] 
40. Guglielmi, V.; Comite, V.; Andreoli, M.; Dematin, F.; Lombardi, C.A.; Fermo, P. Pigments on Roman wall painting and stucco fragments from the Monte d'Oro Area (Rome): A multi-technique approach. Appl. Sci. 2020, 10, 7121. [CrossRef]

41. Paradisi, A.; Sodo, A.; Artioli, D.; Botti, A.; Cavezzali, D.; Giovagnoli, A.; Polidoro, C.; Ricci, M.A. Domus aurea, the 'Sala delle Maschere': Chemical and spectroscopic investigations on the fresco paintings. Archaeometry 2012, 4, 1060-1075. [CrossRef]

42. Piovesan, R.; Siddall, R.; Mazzoli, C.; Nodari, L. The temple of Venus (Pompeii): A study of the pigments and painting techniques. J. Archaeol. Sci. 2011, 38, 2633-2643. [CrossRef]

43. Sbroscia, M.; Cestelli-Guidi, M.; Colao, F.; Falzone, S.; Gioia, C.; Gioia, P.; Marconif, C.; Mirabil Gattia, D.; Loreti, E.M.; Marinelli, M.; et al. Multi-analytical nondestructive investigation of pictorial apparatuses of "Villa della Piscina" in Rome. Microchem. J. 2020, 153, 404-420. [CrossRef]

44. Tarquini, O.; Pronti, L.; Lorenzetti, E.G.; Felici, A.C. Pigment identification on campana reliefs from the palatine hill and colosseum valley in Rome. J. Cult. Herit. 2020, 43, 294-302. [CrossRef]

45. Vadrucci, M.; Mazzinghi, A.; Sorrentino, B.; Falzone, S.; Gioia, C.; Gioia, P.; Loreti, E.M.; Chiari, M. Characterisation of ancient Roman wall-painting fragments using non-destructive IBA and MA-XRF techniques. X-ray Spectrom. 2020, 49, 668-678. [CrossRef]

46. Alberti, R.; Crupi, R.; Frontoni, R.; Galli, C.; La Russa, M.F.; Licchelli, M.; Majolino, D.; Malagodi, M.; Rossi, B.; Ruffolo, S.A.; et al. Handheld XRF and Raman equipment for the investigation of Roman finds in the Villa deil Quintili (Rome, Italy). J. Anal. At. Spectrom. 2017, 32, 117-129. [CrossRef]

47. Garofano, I.; Perez-Rodriguez, J.L.; Robador, M.D.; Duran, A. An innovative combination of non-invasive UV-Visible-FORS, XRD and XRF techniques to study Roman wall paintings from Seville, Spain. J. Cult. Her. 2016, 22, 1028-1039. [CrossRef]

48. Bracci, S.E.; Cantisani, S.; Falzone, M.M.; Tomassini, P. Archaeometry and Roman painting: The case of pre-hadrianic paintings in Ostia Antica. In La peinture Murale Antique, Méthodes Apports d'une Approche Technique, Actes du Colloque International de Louvain-la-Neuve, 21 Avril 2017 (AIRPA); Cavalieri, M., Tomassini, P., Eds.; Edizioni QUASAR: Rome, Italy, 2021.

49. Falzone, S.; Marano, M.; Tomassini, P. Decorating the harbour of Rome: Dynamics of production and craftsmanship in Ostian wall paintings. In Local Styles or Common Pattern Books in Roman Wall Painting and Mosaics, Proceedings of the Panel 3.22; Thomas, R., Ed.; Proceedings of the XIXth Congress of the Associazione Internazionale di Archeologia Classica (AIAC) 49-64; Propylaeum: Rome, Italy, 2021.

50. Terrapon, N. Les enduits peints du péristyle et de l'œcus 101 de la Domus aux Bucranes: Observations techniques. In Villas, Maisons, Sanctuaires et Tombeaux Tardo-Républicains: Découvertes et Relectures Récentes, Actes du Colloque International de Saint-Romainen-Gal en L'honneur d'Anna Gallina Zevi (Vienne-Saint-Romain-en-Gal, 8-10 Février 2007); Perrier, B., Ed.; Edizioni Quasar: Rome, Italy, 2007; pp. 81-98.

51. Bracci, S.; Cantisani, E.; Cantisani, E.; Conti, C.; Tomassini, P.; Martinad, M. Enriching the knowledge of Ostia Antica painted fragments: A multi-methodological approach. Spectrochim. Acta Part A Mol. Biomol. Spectrosc. 2021, 265, 120260. [CrossRef]

52. Pliny the Elder. Natural History, Book 35; Jones, W.H.S., Translator; Harvard University Press: Cambridge, MA, USA, 1956; pp. 1-100. 